\title{
DA DOGMÁTICA PENAL FUNCIONALISTA DE GÜNTHER JAKOBS E CLAUS ROXIN NO ÂMBITO DA CULPABILIDADE: uma contraposição teórica
}

\author{
ABOUT DOGMATIC OF THE CRIMINAL FUNCTIONALIST BY GÜNTHER \\ JAKOBS AND CLAUS ROXIN IN THE SPACE OF CULPABILITY: \\ contrast theoretical
}

\begin{abstract}
MARA RUBIA MARQUES
Bacharel em Direito pela Universidade Estadual de Londrina, Especialista em Ministério Público no Regime Democrático de Direito pela Fundação Escola do Ministério Público do Paraná/FEMPAR-Universidade Norte do Paraná/UNOPAR, Especialista em Direito Penal, Processo Penal, Direito Civil e Processo Civil pela Universidade

Estadual de Londrina mara.rubia@sercomtel.com.br
\end{abstract}

\begin{abstract}
RESUMO
0 artigo confronta conceitos dos funcionalistas alemães GÜNTHER JABOKS e CLAUS ROXIN, em particular aos que aludem à culpabilidade e a divergência entre os dois autores nesse âmbito visando determinar qual teoria é mais adequada em um ambiente democrático. O exame do tema procede-se da necessidade de o Direito Penal se harmonizar ao paradigma das sociedades complexas visando impedir seu distanciamento da realidade social que poderá acarretar o enfraquecimento de sua eficiência em face das contingências sociais.
\end{abstract}

Palavras-chave: Culpabilidade; Dogmática-penal funcionalista; Sistema social.

\begin{abstract}
The article addresses concepts of German functionalists GÜNTHER JAKOBS and CLAUS ROXIN, in particular aspects that allude to the guilt and the divergence between the two authors in this field to determine which theory is most appropriate in a democratic environment. The examination of the theme comes from the need to harmonize criminal law with the paradigm of complex societies in order to keep their distance from social reality that can lead to the weakening of its efficiency in the face of social contingencies.
\end{abstract}

Keywords: Culpability; Dogmatic-criminal functionalist; Social System.

\section{SUMÁRIO}

INTRODUÇÃO; 1 DO FUNCIONALISMO SISTÊMICO DE GÜNTHER JAKOBS; 2 DO FUNCIONALISMO TELEOLÓGICO-VALORATIVO DE CLAUS ROXIN; CONCLUSÃO; REFERÊNCIAS. 


\section{INTRODUÇÃO}

Nestes tempos indefinidos modernos ou pós-modernos ${ }^{1}$ certamente se conclui que o paradigma é o das sociedades complexas. ${ }^{2}$ É o momento de se repensar o percurso traçado pelo homem quando se constata que o esboço arquitetado pelo positivismo não se sustenta em face da nova configuração de inter-relações em que as fronteiras socioeconômicas e culturais são cada vez menos perceptíveis diante do avanço do fenômeno da Mundialização com novas formas de comunicação pela qual se estabelece uma interdependência “mundializada". Em razão desse contexto é essencial o aporte conferido pelas teorias funcionalistas no domínio do direito penal, tendo em vista o êxito na atenuação das complexidades do sistema social.

O Direito Penal contemporâneo não escapa às interrogações a respeito de sua função nesta nova configuração mundializada e, principalmente, de sua legitimidade como sistema principal para conformar os dois valores que estão no cerne das relações intersubjetivas, a liberdade e a segurança. Entre os dois valores pesam a balança do direito penal. ${ }^{3}$ Para além das relações intersubjetivas as teorias funcionalistas explicam a ligação entre o direito penal e a

\footnotetext{
${ }^{1}$ A respeito da modernidade, diz Krishan Kumar: "a modernidade - a moderna Sociedade industrial recebeu uma análise abrangente dos principais teóricos sociais do século XIX: Hegel, Marx, Tocqueville, Weber, Simmel e Durkheim. Suas análises permanecem relevantes em muitos aspectos para as sociedades dos dias atuais - Marx incluído, apesar do fracasso do socialismo de estado em várias partes do mundo. Mas o crescimento de certos aspectos em nosso tempo - a globalização da economia, o declínio do estado-nação, as grandes migrações populacionais - levaram alguns pensadores a postular o fim da modernidade tal como esta sempre foi em geral compreendida. [...] (apud GOMES, 2010, p. 55). Sobre a pós-modernidade, merece referência o sociólogo Zygmunt Bauman. Para ele, "o que é realmente novo na nossa atual situação, em outras palavras, é o nosso ponto de observação. Embora ainda bem próximos da era moderna e sentindo os efeitos da turbulência que ela provocou, podemos agora (melhor ainda, estamos preparados para e dispostos a) ter uma visão fria e crítica da modernidade na sua totalidade, avaliar o seu desempenho, julgar a solidez e congruência da sua construção. É isso, em última análise, que representa a ideia de pós-modernidade: uma existência plenamente determinada e definida pelo fato de ser 'pós', posterior, e esmagada pela consciência dessa condição. [...]. (BAUMAN apud GOMES, 2010, p. 55).

2 “[o] cenário teórico esboçado no século XX [representa] uma profunda mudança paradigmática na ciência em geral, com o surgimento de um novo fator, que vai provocar a ruptura do modelo newtoniano, ou seja, 'desferir o golpe de misericórdia na visão clássica do mundo - a complexidade'. (BASARAB apud NEVES; NEVES, 2006, p.182, 183).

${ }^{3}$ Em torno do binômio segurança-liberdade entende o sociólogo polonês Zygmunt Bauman circundam a ambivalência da vida. A indagação está em encontrar "a fórmula de ouro" que é a "mistura perfeita" entre os dois valores essenciais para uma vida feliz. Disse o sociólogo: "segurança sem liberdade é escravidão; liberdade sem segurança é um completo caos". Entende o sociólogo que hoje o pêndulo está iniciando um movimento para o lado da segurança. (BAUMAN, 2012).
} 
sociedade e cada categoria do delito (conduta, tipicidade, antijuridicidade e culpabilidade) é estruturada com foco nesse vínculo.

A provocação para a pesquisa do funcionalismo resulta da proximidade entre direito penal e as políticas criminais. Defende-se a conciliação do direito penal com a realidade pela influência das políticas criminais. Apenas como exemplo descritivo em que se reconhece essa aproximação cita-se a década de 1990 na qual se propagou em Nova lorque a política criminal da “Tolerância Zero" que difundia a ideia de instalar a segurança na cidade. Apesar de o planejamento orientar-se pela função do direito penal - segurança social - não se pode descuidar do caráter instrumental que eventualmente vicia todo o mecanismo, ${ }^{4}{ }^{5}$ bem como menosprezar a liberdade individual na regulação do permitido e proibido. ${ }^{67}$

\footnotetext{
${ }^{4}$ Noam Chomsky esclarece como os EUA "controlam o crime". O motivo de se aumentar o controle da criminalidade é a existência de uma "enorme população supérflua" que precisa ser "trancafiada". Em meados nos anos 1980 os EUA passaram a ter a mais alta população carcerária per capita. Diz o pensador: [...] nos Estados Unidos, hoje, isso também está relacionado à questão racial, por inúmeros motivos, e volta-se, portanto, contra os homens negros e latinos. Quero dizer, essa é principalmente uma guerra contra a população supérflua, que é a classe de trabalhadores pobres - mas a correlação raça/classe é tão próxima nos centros urbanos que, quando se vai atrás da classe de trabalhadores pobres, se está perseguindo principalmente os negros. Então, há essas espantosas disparidades raciais nas estatísticas criminais por toda parte. E a questão é que os pobres urbanos são, da perspectiva do poder, um tipo de população inútil, realmente não contribuem para se conseguirem lucros e então, como resultado, querem livrar-se deles - e o sistema de justiça criminal é um dos melhores meios de fazê-lo." (MITCHELL; SCHOEFFEL, 2005, p. 495-496). Na literatura o personagem imigrante Karl Rossmann recém chegado à América disse sobre o país: "[...] existe muita prevenção aqui contra os estrangeiros"; responde o "foguista": Você já está inteirado também disso? Pois não está mal". (KAFKA, 2000, p. 26).

5 "O movimento da Tolerância Zero, sob influência da Teoria das Janelas Quebradas, foi lema de campanha e depois, rigorosamente cumprido, pelo promotor Rudolph Giuliani, durante sua gestão à frente da Prefeitura Municipal de Nova York, a partir de 1993. Prova da aplicação indiscricionada da teoria, ampliando o campo de atuação do Direito Penal, é a citada, pelo próprio Rudolph Giuliani em seu livro $\mathrm{O}$ Líder, onde afirma que 'a teoria das 'Janelas Quebradas' [...] convenceu-me de que o combate a 'pequenas' infrações, como mendicância agressiva, pichação em muros e paredes, passagem por cima de 'borboletas' de controle de passagem, contribuem para a redução substancial da criminalidade, inclusive em termos de delitos graves"”. (TRINDADE; SCHWARTZ apud MATZENBACHER; TONET, 2008, p. 259). Em 2010 a filha de Rudolph Giuliani foi surpreendida furtando em uma loja de cosméticos, porém, no caso dela não houve denúncia do Ministério Público. Notícia publicada no jornal 0 Globo Online. (FILHA DE RUDOLPH GIULIANI..., 2012). Há notícia de que Rudolph Giuliani foi contratado como consultor de segurança pelo Rio de Janeiro para os Jogos Olímpicos de 2016; o ex-prefeito de Nova lorque foi contratado ao preço (suposto) de U\$4,3 milhões pela Cidade do México em 2003. (HERNANDES, 2011).

${ }^{6}$ Em maio de 2001 a Suprema Corte dos Estados Unidos decidiu a imediata antecipação da soltura de cerca de 46.000 presos e a redução da população carcerária para 110.000 (que já ultrapassa a capacidade máxima de abrigamento carcerário); naquela ocasião os EUA contavam com uma população carcerária em torno de 140.000 pessoas. (LIPTAK, 2011)
} 
Visando estabelecer a teoria penal funcionalista que mais apropriadamente - em consonância com o Estado Democrático de Direito - equilibra os dois valores segurança e liberdade o artigo confronta os conceitos dos alemães Günther Jakobs e Claus Roxin, em especial, no âmbito da culpabilidade ${ }^{8}$ em que se distingue de movo evidente os reflexos de cada teoria provenientes da conexão dessa categoria analítica do crime com os fins da pena. Aplica-se o método dedutivo tendo em vista a elaboração de proposições textuais a partir da pesquisa bibliográfica.

\section{DO FUNCIONALISMO SISTÊMICO-RADICAL DE GÜNTHER JAKOBS}

A dogmática-penal difundida por Günther Jakobs é influenciada pela teoria dos sistemas de Niklas Luhmann. Não é novidade que o homem busca ordenar seu ambiente através de uma racionalidade. ${ }^{9}$ No paradigma da sociedade complexa no qual se fundamentam as novas ciências perseguem-se instrumentos que nos facilitem a compreensão da nossa vivência. Niklas Luhmann propõe a teoria dos sistemas como alternativa de apreensão da sociedade complexa e institui espaços delimitados (os sistemas) que possibilita a compreensão do funcionamento de cada sistema por uma identidade estrutural. ${ }^{10}$ Celso Fernandes Campilongo explica a teoria luhmanniana pela diferença entre sistema e ambiente quando aponta que "o conceito de ambiente se explica pela noção de 'realidade' ou de 'mundo circundante' que engloba tudo” e os sistemas são "demarcados por conceitos diferenciais, que acabam por constituir uma determinação (unidade)" cujos limites reduzem a complexidade do ambiente que é vastíssimo. ${ }^{11}$ Em complemento à conceituação acrescenta a explicação de uma categoria que é chamada de

${ }^{7}$ No Brasil há Repercussão Geral em RE no 580252-MS cuja Ementa trata da "questão constitucional atinente à contraposição entre a chamada cláusula da reserva financeira do possível e pretensão de obter indenização por dano moral decorrente da excessiva população carcerária." (BRASIL, 2008).

${ }^{8}$ Para pesquisa comparativa das teorias funcionalistas no âmbito da teoria da ação ver artigo "Uma análise da contribuição do funcionalismo de Claus Roxin à teoria da ação", de Mariana Martins de Castilho Fonseca. (FONSECA, 2009).

${ }^{9} \mathrm{Na}$ Grécia antiga a racionalidade revelava-se por uma ordem atribuída à physis.

10 "Essa complexidade extrema do mundo, nesta forma, não é compreensível pela consciência humana. A capacidade humana não dá conta de apreensão da complexidade, considerando todos os possíveis acontecimentos e todas as circunstâncias no mundo. Ela é, constantemente, exigida demais. Assim, entre a extrema complexidade do mundo e a consciência humana existe uma lacuna. E é neste ponto que os sistemas sociais assumem a sua função. Eles assumem a tarefa de redução de complexidade. Sistemas sociais, para Luhmann (1990), intervêm entre a extrema complexidade do mundo e a limitada capacidade do homem em trabalhar a complexidade." (NEVES, 2006, p. 191).

${ }^{11}$ CARVALHO, 2009, p. 115. 
'função' por Niklas Luhmann a qual vai direcionar a dogmática-penal de Günther Jakobs. Por função, segundo Fabiana Del Padre Tomé, “entende-se toda ação ou atividade que o sistema desenvolve visando atingir seus objetivos" que são cumpridos "mediante determinações estruturais". ${ }^{12}$

Os pressupostos luhmannianos são tidos como orientadores da teoria de Günther Jakobs o qual afirma que o direito penal é um sistema que tem função própria. A teleologia do direito penal "é a estabilização do próprio sistema [penal]" que se cumpre mediante "a estabilização das normas [penais] de modo que a imputação decorrerá da infração à norma enquanto violação às expectativas sociais" de que as normas serão cumpridas por todos. ${ }^{13}$

A dogmática-penal sob a perspectiva assinalada prioriza a função do sistema radicalizando a aplicação do direito penal na medida em que "o Direito penal não pode reagir em face de um fato enquanto lesão de um bem jurídico, mas somente contra o fato enquanto violação da norma". ${ }^{14}$ É uma concepção reducionista do direito penal que potencialmente guarda perigosa proximidade com a arbitrariedade.

O sistema penal jakobsiano é concebido a partir da manutenção das expectativas de que as normas jurídicas não sejam violadas. A sanção penal, portanto, condiz com o reforço ao panorama abstrato que circunda a teoria apontada visto que a previsão normativa é aplicada para proteger a expectativa de cumprimento das normas do sistema penal, renunciando, por conseguinte, um direito penal orientado à proteção de bens jurídicos. ${ }^{15}$

Desse prisma os fundamentos teóricos são criticados em virtude de limitarem a concepção do Direito Penal à função preventiva geral positiva. ${ }^{1617}$ Manuel José Arias Eibe

12 Ibid., p. 116.

13 Tradução livre de: “el fin Del Derecho penal es la estabilización del mismo sistema social mediante la estabilización de las normas en el referido sistema, de manera que la imputación derivará de la infracción de la norma en cuanto que ifracción de las expectativas sociales". (EIBE, 2006, p. 446, 447).

${ }^{14}$ Tradução livre de: “[...] el Derecho penal no puede reaccionar frente a um hecho em cuanto lesión de um bien jurídico, sino sólo frente a un hecho en cuanto quebrantamiento de la norma". (EIBE, 2006, p. 447).

${ }_{16}^{15}$ EIBE, 2006, p. 449.

16 “[...] as chamadas teorias da prevenção geral positiva ou 'prevenção-integração' ressaltam que a pena ratifica a vigência do Direito como mecanismo regular das condutas e restabelece sua eficiência diante das ameaças que o delito traz consigo e, além disso, a pena atuaria como instrumento de configuração da consciência jurídica coletiva, dado que sua aplicação restabelece, ao fim, a confiança e a fidelidade do cidadão à norma jurídica". Tradução livre de: “[...] las llamadas teorías de la prevención general positiva o 'prevención-integración' resaltan que la pena afirma la vigencia del Derecho como mecanismo regulador de las conductas y lo restablece en su calidad de tal ante las amenazas que el delito trae consigo e incluso, más allá, que la pena actuaría como mecanismo de conformación de la conciencia 
assegura que o Direito Penal cumpre a função preventiva geral positiva, entretanto, não é a sua única e tampouco principal missão visto que suscita incertezas concernentes à legitimação do próprio sistema de Direito Penal. A sociedade e os indivíduos participam de um constante movimento que os transformam e os modificam, logo, pressupõe-se uma realidade dinâmica que se contrapõe a um sistema que intenciona sustentar-se em si mesmo apartado das contingências e complexidades que configuram a ambiência humana. ${ }^{18}$ A legitimidade sistêmica não é apreciada pela teoria jakobsiana considerando que em sua estrutura teórica "não faz parte do conhecimento da norma que se aceite como correto o conteúdo, sendo que basta o conhecimento do que a vulneração da norma supõe no ordenamento social existente [...] uma perturbação". ${ }^{19}$

Compreende que a prevenção geral positiva é ramificada em tríplice dimensão: 1) confiança na norma; 2) fidelidade ao Direito; 3) aceitação das consequências pela violação da norma. Assim, pela imposição de sanções penais entreve a preservação e o fortalecimento do ordenamento jurídico sob a perspectiva da norma e do princípio da conservação do Direito, ao passo que, sob o ângulo da sociedade que pune se busca a pacificação social. ${ }^{20}$

A conformação da teoria do sistema luhmanniano proposta por Günther Jakobs, supracitado em linhas gerais, afigura controverso ao exame de Evaristo Prieto Navarro. 0 pesquisador registra três observações nas quais concebe exigir correções à dogmática penal jakobsiana. Em primeiro lugar entende controversa a forma pela qual a teoria dos sistemas de Niklas Luhmann ${ }^{21}$ foi recepcionada pela ciência penal de Günther Jakobs o qual prescinde

jurídica colectiva, dado que su aplicación restablece al cabo la confianza y la fidelidad del ciudadano a la norma jurídica. (NAVARRO, 2000, p. 265).

${ }^{17}$ Essa é a escala da concepção teórica de Jakobs (2003, p. 32): “Por meio da ameaça da pena e da pena pode-se dirigir a vontade e por meio da vontade dirigida pode-se manter diretamente uma configuração social determinada [...]. Portanto, a direção da vontade é idônea para compensar a debilidade da norma. [...] Por conseguinte, trata-se de prevenção geral por intermédio da prática de fidelidade à norma." Explica o penalista alemão em seguida por que prevenção geral positiva: "prevenção geral porque (sic) pretende-se produzir um efeito em todos os cidadãos; positiva, porque esse efeito não se pretende que consista em medo diante da pena, e sim em uma tranquilização no sentido de que a norma está vigente, de que a vigência da norma, que se viu afetada pelo fato, voltou a ser fortalecida pela pena [...]". (JAKOBS, 2003, p. 35).

${ }_{18}^{18}$ EIBE, 2006, p. 449.

19 JAKOBS, 2003, p. 24.

${ }^{20}$ NAVARRO, 2000, p. 285.

21 "La diferencia sistema/entorno es el punto de partida del planteamiento de la teoría de los sistemas de Luhmann. Un sistema no puede darse independientemente de su entorno, en cuanto que se constituye precisamente al trazer, mediante sus operaciones, un límite que lo distingue de lo que como ambiente, no le pertenece. [...] Fijar un límite no significa aislar al sistema. Las operaciones siempre son internas, 
determinar, por exemplo, qual o alcance e as limitações das categorias sistêmicas no âmbito da prevenção geral positiva. ${ }^{22} \mathrm{Na}$ segunda observação, compreende que no último giro da teoria sistêmica de Niklas Luhmann pelo qual apresentou o Direito como um sistema autopoiético (no início de 1980) não se pode afirmar que restringiu a função da pena à proteção do ordenamento jurídico, à fidelidade à norma jurídica ou ao reforço da consciência normativa coletiva que seria enfraquecida pela prática do delito. Por fim, no terceiro apontamento assevera que os pressupostos da teoria sistêmica de Luhmann utilizados para interpretação da realidade não auxiliam, mas ao contrário, impossibilitam a construção de uma teoria sob o prisma do que pretende a teoria da prevenção geral positiva. ${ }^{23}$

A estrutura da dogmática penal de Günther Jakobs pela qual se reduz a pena à função preventiva geral positiva repercute na esfera da culpabilidade. 0 radicalismo da teoria é exposto no seguinte contraponto: "a pena que é útil para a consecução de seus fins sociais, se não está limitada pelo princípio da culpabilidade, trata como coisa a pessoa que vai ser submetida a ela”, por outro lado, na sua concepção funcionalista a limitação da pena pelo princípio da culpabilidade retira a funcionalidade da pena. ${ }^{24}$ Nesse contexto a culpabilidade não está vinculada ao princípio limitador do poder estatal, mas como imputação ao infrator e com a finalidade precípua de revigorar a advertência de que a norma tem de ser acatada. Dessa forma enfatiza: “a finalidade da culpabilidade é a estabilização da norma débil” - passível de violação. $^{25}$

A estruturação do direito penal como um sistema no qual a sanção penal atende à proteção do próprio sistema - com a função de assegurar credibilidade na expectativa de que as normas jurídicas estruturadas no reduto do sistema penal serão cumpridas pela coletividade e que eventual prática delituosa pode provocar a quebra da confiança na norma - repercute nas categorias analíticas do crime, tipicidade, antijuridicidade e culpabilidade. 0 artigo será

pero desde el nivel de la observación el límite puede ser trascendido y se constatan varias formas de interdependencia entre sistema y entorno." (CORSI; ESPOSITO; BARALDI, 1996, p. 149).

${ }^{22}$ Carvalho $(2009$, p. 116) alude a algumas categorias e explica que: "por função entende-se toda ação ou atividade que o sistema desenvolve, visando atingir seus objetivos. 0 cumprimento desta função só é possivel mediante determinações estruturais denominadas de 'código' e 'programa'. O código é um esquema binário invariável, produzido no implemento da função, que fundamenta a identificabilidade do sistema, permitindo separá-lo de seu ambiente. É por meio dele que os elementos de fora são processados para dentro do sistema. Para que os códigos cumpram seu papel na produção de elementos internos ao sistema, no entanto, impõe-se a existência de programas que os complementem, conferindo-lhes conteúdo.

${ }^{23}$ NAVARRO, 2000, p. 266-268.

24 JAKOBS, 2003, p. 12.

${ }^{25}$ Ibid., p. 31. 
circunscrito à divergência entre as teorias funcionalistas já mencionadas no âmbito da culpabilidade.

Acerca da prevenção geral positiva Rafael Alcácer Guirão observa que a raiz da qual deriva a corrente teórica assinalada é a tradição utilitarista evidenciada pelo caráter maximizante do bem estar da coletividade, "podendo desprezar, em razão de tal objetivo, a liberdade do indivíduo concreto". ${ }^{26}$

A aplicação da dogmática penal de Günther Jakobs esvazia o conteúdo limitador do poder estatal que se firma na evolução conceitual da culpabilidade. ${ }^{27}$ Tendo por fim a estabilização da norma pela expectativa de seu cumprimento concebe a culpabilidade "como responsabilidade por um déficit de motivação jurídica dominante, em um comportamento antijurídico [...]; a culpabilidade corresponde a uma infidelidade ao direito". ${ }^{28}$ A preservação da expectativa normativa sobrepõe a qualquer outro interesse, razão pela qual Rafael Alcácer Guirão $^{29}$ evoca Kant e assenta que a aplicação desse direito penal não distingue o Direito das pessoas e o Direito das coisas. Conclui por uma expressão instrumentalizada da culpabilidade, pois, "pune o sujeito para manter a confiança geral na norma”. ${ }^{30} \mathrm{Em}$ alusão a tal conclusão Günther Jakobs reafirma que sua concepção somente descreve "as condições de funcionamento de toda a sociedade [e] uma descrição não instrumentaliza, e sim em todo caso descobre instrumentalizações existentes há muito tempo". ${ }^{31}$

Nesse sentido, infere Sebástian Borges de Albuquerque Mello que "a tese de Jakobs permite que um homem seja utilizado como mecanismo estabilizador da ordem normativa, deslocando o centro da ordem jurídica, que não mais é o ser humano, mas sim a prevalência do sistema". ${ }^{32}$ A culpabilidade assume um caráter formal e abstrato, aliás, é uma crítica também endereçada a Niklas Luhmann a quem se atribui a concepção de uma "sociedade sem homens". ${ }^{33}$ A abstrativização da culpabilidade decorre de Günther Jakobs centrar a imputação no sistema e

\footnotetext{
${ }^{26}$ GUIRÃO, 2002, p. 140.

${ }^{27}$ MELLO, 2010, p. 263.

28 Ibid., p. 284.

${ }^{29}$ GUIRÃO, 2002, p. 141.

${ }^{30}$ MELLO, 2010, p. 285.

31 JAKOBS, 2003, p. 37.

${ }^{32}$ MELLO, 2010, p. 285.

${ }^{33}$ NAVARRO, 2000, p. 277.
} 
não no ser humano. ${ }^{34} 0$ próprio penalista confirma que seu sistema exclui conceber "o destinatário da imputação antes da sociedade”. ${ }^{35}$

Partindo do cálculo expansionista Rafael Alcácer Guirao incita uma reflexão prática da teoria; principia exemplificando que ao se ocuparem do tema inimputabilidade, os adeptos da teoria funcionalista radical argumentam que as proibições penais não perdem o caráter estabilizador da norma pela violação praticada por um inimputável por ser isento de responsabilidade penal; por outro lado, Guirao controverte: se um inimputável for punido é possível que a estabilização da norma robusteça seu caráter inibitório aos imputáveis. Complementam aqueles que o pensamento dos imputáveis seria: aos inimputáveis não se aplica a pena, mas, como não sou como eles (inimputável) a mim será aplicada a pena; este contesta novamente ${ }^{36}$, maximiza a função do sistema na perspectiva instrumental e contra-argumenta: na finalidade de proteção do sistema a punição de um inimputável reforça o poder da norma perante o imputável que pensaria: se punem um inimputável, o que não farão comigo que sou imputável! Conclui a controvérsia: “[...] a punição de inimputáveis aumentaria a efetividade preventiva, e uma teoria utilitarista que fundamente a pena exclusivamente na referida lógica tem que partir sempre da efetividade do fim perseguido". ${ }^{37}$

Cita-se uma amostra do raciocínio fundamentado na dogmática penal funcionalista radical que foi matéria de discussão no Supremo Tribunal Federal através do HC 101874/SC. ${ }^{38}$ Pelo voto do Ministro relator depreende-se que a motivação do juízo de primeiro grau para se decretar a prisão cautelar do acusado circunscreveu-se também [à necessidade de] segregação cautelar, sob pena de se abalar a ordem pública local, com reflexo direto na imagem de um dos poderes do Estado. É a aplicação do direito penal para a proteção da reputação do sistema normativo. Não é o que tem sido aplicado no Tribunal “Guardião da Constituição”. Em consonância com o alerta de Konrad Hesse, "não é [...] em tempos tranquilos e felizes que a Constituição normativa vê-se submetida à sua prova de força. Em verdade, esta prova dá-se nas situações de emergência, nos tempos de necessidade." 39

\footnotetext{
${ }^{34}$ MELLO, 2010, p. 285.

35 JAKOBS, 2003, p. 37.

${ }^{36}$ GUIRÃO, 2002, p. 150.

37 Tradução livre de: “[...] la punición de inimputables aumentaria la efectividad preventiva, y uma teoría utilitarista que fundamente la pena exclusivamente en dicha lógica tiene que partir siempre de la efectividad del fin perseguido." (GUIRÃO, 2002, p. 150).

${ }^{38}$ Habeas Corpus 101874/SC. DJe 159. Publicado em 27-08-2010. (BRASIL, 2010).

39 HESSE, 1991, p. 25.
} 
A partir de 1993 Günther Jakobs altera a concepção sistêmica da sociedade para uma perspectiva interpessoal. A diferença entre as concepções é o deslocamento da comunicação instrumental dirigida aos fins para o reconhecimento de uma sociedade composta por pessoas autônomas, capazes de 'competência de discurso' porque somente assim será possível “criar uma ordem normativa [...] que estabelecerá regras de convivência as quais todos deverão se submeter". ${ }^{40}$

Apesar da abertura no sistema jakobsiano, aponta-se uma inquietação na reestruturação decorrente do giro conceitual: o conceito do princípio de igualdade. A ordem normativa é dirigida àqueles que a sociedade recepciona como iguais, ou seja, se um ser humano não se adequar aos limites entendidos pela sociedade como razoáveis de serem tolerados deixará de ser 'igual' e será irrogado como 'algo irracional'. Nessa perspectiva a culpabilidade agora é voltada ao "fim de reafirmar a identidade normativa da sociedade". ${ }^{41}$

O autor da cidade de Bonn conforma estruturalmente o sistema atribuindo qualificações aos indivíduos dependendo do papel que se espera ser desempenhado. Todos os indivíduos devem desempenhar papéis no sistema. O papel "comum" é o de "comportar-se como uma pessoa comum em Direito [...] o de respeitar os direitos dos demais como contrapartida ao exercício dos próprios direitos. [...] Esse papel comum tem o conteúdo positivo de constituir a própria pessoa como pessoa em Direito [...]. ${ }^{42}$ José Luis Díez Ripollés enfatiza que a partir desses pressupostos não se reconhece a pessoa como conceito originário, mas como "algo que é atribuído ao indivíduo como produto da comunicação dentro do sistema social, atribuição que dependerá do grau de satisfação das expectativas normativas que o indivíduo [presta]". 4344 Nesse extremo, Diógenes seria filósofo ou contraventor? ${ }^{45}$

A partir dessa concepção justifica-se um possível embasamento para a legitimação de um direito penal do inimigo que não será objeto abordado nesse artigo ${ }^{46}$, entretanto, merece

40 GUIRÃO, 2002, p. 166.

41 GUIRÃO, 2002, p. 166.

42 JAKOBS, 2000, p. 55.

43 RIPOLLÉS, 2007, p. 574.

${ }^{44} \mathrm{Na}$ nascente do Direito Penal estruturado visando à garantia do indivíduo em face do Estado alertava Cesare Beccaria (1764): “não haverá liberdade toda vez que as leis permitirem que, em certas circunstâncias, o homem cesse de ser pessoa e se torne coisa." (BECCARIA, 2005, p.81).

45 Diógenes foi um filósofo grego que viveu no século $\mathrm{V}$ a.C. e apregoava renúncia às riquezas e aos padrões sociais da sociedade grega de sua época; o filósofo morava na rua e praticava a existência similar a de um cão.

46 “Inimigo, na concepção de Jakobs, é um cidadão que por sua posição, forma de vida, raça, religião ou por pertencer a uma organização, recuse-se de maneira definitiva a cumprir as normas jurídicas. Ao se 
registro o alerta conclusivo de Eduardo Diniz Neto quanto à índole de desconfiguração do indivíduo ao ser infligido como inimigo em decorrência de que "o inimigo, sequer pode figurar ou ser incluído dentre os tutelados por uma constituição cidadã, devendo [...] ser interceptado previamente e assim combatido por sua injustificável periculosidade e, ainda que atávica, danosidade social". ${ }^{47}$

A teoria funcional sistêmico-radical contribui para a compreensão da relação entre sociedade e direito penal considerando a estruturação mais encerrada que resulta em uma atenuação da complexidade do sistema social. Porém, a culpabilidade reduzida à função preventiva geral visando assegurar a credibilidade do sistema penal evidencia um caráter instrumentalizado com possível risco de se expandir até um direito penal do inimigo. Outra teoria que conceitualmente concilia culpabilidade com a função da pena é chamada de funcionalismo teleológico-valorativo, considerada uma teoria mais moderada apresentada por Claus Roxin.

\section{DO FUNCIONALISMO TELEOLÓGICO-VALORATIVO DE CLAUS ROXIN}

Em contraposição ao funcionalismo sistêmico jakobsiano segue a exposição da teoria penal de Claus Roxin, alemão de Hamburgo, que critica o caráter instrumental do sistema penal concebido por Günther Jakobs, entretanto, defende similarmente que o direito penal tem o seu contorno direcionado ao aspecto funcional. Esse penalista refuta expressamente a dogmática penal de Günther Jakobs à concepção kantiana de dignidade da pessoa humana quando assinala que "a instrumentalização do indivíduo que serve apenas como instrumento dos interesses sociais de estabilização" viola a dignidade da pessoa humana. ${ }^{48}$

recusar de maneira definitiva a cumprir a lei [...] encontra-se fora do sistema e não tem direito a gozar dos benefícios dos mesmos (ou seja, das garantias fundamentais)". Tradução livre de: "Enemigo, em concepto de Jakobs, es um ciudadano que por sua posición, forma de vida, raza, religión o pertenecia a uma organización, há huido de maneira duradera del derecho. Al Haber huido de manera duradera de la ley [...] al encontrarse fuera del sistema, no tiene derecho a gozar de los benefícios del mismo".(DíAZ, 2010.).

${ }^{47}$ DINIZ NETO, 2010, p. 214.

${ }^{48}$ Tradução livre de: "Una instrumentalización tal del individuo, que solo sirve ya como instrumento de los intereses sociales de estabilización, fue criticada por Kant como violación de la dignidad humana". (ROXIN, 2006, p. 806). 
A proposta do funcionalismo teleológico-valorativo de Claus Roxin é reconstruir a estrutura lógico-objetiva do finalismo de Welzel objetivando a aproximação do direito penal com a realidade prática tendo em vista que as soluções dogmáticas apresentam, indubitavelmente, resultados insatisfatórios no aspecto prático. ${ }^{49}$

A estrutura do funcionalismo moderado é concebida a partir de um sistema aberto, não apartado da realidade social. Com esse intuito insere os estudos da Política Criminal como forma de orientar o Direito Penal a apresentar soluções mais congruentes com a realidade prática. É a perspectiva prática que circundará a teoria penal de Claus Roxin o qual expressamente acentuou que "o Direito penal se justifica por sua efetividade na solução dos problemas da realidade social”. ${ }^{5051}$

São relevantes as análises que conduzam a evitar ou reduzir a limites razoáveis a incidência de crimes. Nesse aspecto o Direito Penal é considerado pelo seu caráter preventivo agregado ao aspecto de que a pena é estudada pelo mesmo critério de prevenção; para o autor ora comentado "o fim da pena é tanto a prevenção geral (positiva ou integradora), como a prevenção especial". ${ }^{52}$ Consoante pontua Eibe "todas as categorias dogmáticas em Roxin devem ser entendidas a partir dos fins da pena os quais se originam do próprio sistema social". ${ }^{53}$ No artigo em que demarca a dogmática penal alemã normativista e a teleológico-valorativa, Manuel José Arias Eibe, em nota de rodapé, demarca a orientação da teoria penal de Claus Roxin, assentando que,

a partir desta nova perspectiva os conceitos (tipicidade, antijuridicidade e culpabilidade) se funcionalizam, ou seja, exige-se que se obtenha deles resultados justos e adequados segundo configurado pelo sistema. Neste sentido, a concepção roxiniana parte de que o dogmático deve, em primeiro lugar, averiguar qual valoração político criminal subjaz em cada um dos conceitos ou categorias da teoria de delito, e, uma vez determinada dita valoração funcionalizar o conceito (ou categoria) que significa construir e desenvolver o

\footnotetext{
${ }^{49}$ Como exemplo aumento da população carcerária, alto índice de reincidência, pouca efetividade nos programas de reeducação e reinserção social dos egressos. (EIBE, 2006, p. 440).

50 Tradução livre de: "[....] el Derecho penal se justifica por su efectividad en la solución de los problemas de la realidad social”. (EIBE, 2006, p. 442).

51 Eduardo Diniz Neto ressalta a atemporalidade do conceito de "política criminal" de Feuerbach abrangido como "conjunto representativo de procedimentos através dos quais, dentro de diversas tendências, o corpo social virtualmente organiza as respostas ao fenômeno criminal, não só no âmbito do direito penal, passando, necessariamente, também por políticas públicas de inclusão social e mudança de paradigmas culturais." (DINIZ NETO, 2010, p. 203).

${ }^{52}$ EIBE, 2006, p. 442.

${ }^{53}$ Tradução livre de: "Todas las categorías dogmáticas en Roxin deben ser entendidas desde los fines de la pena, que vienen dados por el proprio sistema social”. (EIBE, 2006, p. 442).
} 
${ }_{54}$ mesmo de maneira que responda a função que lhe é própria de um modo idôneo.

Embora a teoria penal aludida repercuta na categoria penal do injusto, circunscrever-se a pesquisa ao âmbito da culpabilidade objetivando estabelecer confronto com o esboço jakobsiano firmado anteriormente. Claus Roxin não antevê uma sociedade sem Direito Penal e sem crimes cuja ocorrência é - no entendimento do autor - decorrente da própria natureza imperfeita do ser humano, portanto, propõe que o Direito penal seja um canal a serviço da sociedade dispondo de um ordenamento punitivo mais humano e mais justo. ${ }^{55}$

No contexto da culpabilidade introduz a categoria "responsabilidade" na qual se juntam os conceitos de culpabilidade e da prevenção que conecta, similarmente ao funcionalismo sistêmico-radical, a culpabilidade e os fins da pena. Explica que "a responsabilidade depende de dois dados que devem se juntar ao de injusto: a culpabilidade do sujeito e a necessidade preventiva da sanção penal que deve ser deduzida pela lei", ${ }^{56}$ logo após, conclui que o motivo pelo qual se deve considerar a necessidade preventiva no âmbito da culpabilidade decorre da própria disposição em que assenta o direito penal em virtude de que "quando o legislador descreve uma conduta típica parte-se da ideia de que a conduta será combatida normalmente por meio de uma pena quando concorrerem antijuridicidade e culpabilidade". ${ }^{57}$

Com essa conformação avalia preencher os requisitos exigidos pelo princípio da dignidade da pessoa humana. A conexão entre o conceito de responsabilidade e a teoria dos fins da pena para o penalista robustece o caráter limitador da culpabilidade; afirma que "há uma diferença fundamental entre utilizar a ideia de culpa para colocar o particular à mercê do

\footnotetext{
${ }^{54}$ Tradução livre de: "Desde esta nueva perspectiva los conceptos se funcionalizan, es decir, se les exige que logren resultados justos y adecuados en el marco del desempeño de un adecuado papel en el sistema. En este sentido, la concepción roxiniana parte de que el dogmático debe, en primer lugar, averiguar qué valoración político criminal subyace en cada uno de los conceptos o categorías de la teoría del delito, y una vez determinada la misma funcionalizar dicho concepto o categoría, es decir, construir y desenvolver el mismo de manera que responda a la función que le es propia de un modo idóneo". (EIBE, 2006, p. 441).

${ }^{55} \mathrm{EIBE}, 2006$, p. 442.

56 Tradução livre de: "La responsabilidad depende de dos dados que deben añadirse al injusto: de la culpabilidad del sujeto y de la necesidad preventiva de sanción penal, que hay que deducir de la ley". (ROXIN, 2006, p. 792).

57 Tradução livre de: "[...] cuando el legislador plasma uma conducta en un tipo, parte de la Idea de que debe ser combatida normalmente por medio de la pena cuando concurren antijuridicidad y culpabilidad." (ROXIN, 2006, p. 792).
} 
Estado e empregá-la para o preservar do abuso do referido poder". ${ }^{58}$ Desse prisma, a pena só será aplicada ao indivíduo culpável e se a pena ainda for necessária para cumprir seu papel preventivo.

0 autor contesta o argumento que afirma eventual insegurança jurídica na estrutura conceitual roxiniana considerando que ao juiz, no caso concreto, é facultado a não aplicação da sanção penal por ser desnecessária em seu fim preventivo. Contra-argumenta explicando que “não é possível ao juiz isentar de pena conforme suas próprias representações político-criminais, mas deve se certificar pelas hipóteses preventivas baseadas na lei". ${ }^{59}$ Afirma, sobretudo, que as atuais concepções do direito são configuradas a partir da interpretação, mesmo a dogmática jurídico-penal, portanto, o sistema jurídico comporta determinado espaço de liberdade. ${ }^{60}$ Conveniente o exemplo registrado no artigo de Carlos Miguel Villar de Souza Junior em que indica a situação da "tábua de salvação", na qual se exclui a culpabilidade por inexigibilidade de conduta diversa como reflexo direto da interpretação do elemento culpabilidade conectado com a necessidade preventiva da aplicação da pena. ${ }^{61}$

Além de acrescentar a prevenção especial no âmbito da culpabilidade reforça um direito penal configurado pelo Estado Democrático de Direito que concretiza na aplicação da pena o princípio da dignidade da pessoa humana propondo medidas punitivas alternativas à privação da liberdade. Aproxima a política criminal também do âmbito punitivo ao preconizar que algumas sanções que não privam o indivíduo de sua liberdade são tão eficientes preventivamente quanto à aplicação da privação da liberdade razão pela qual aquelas devem ser impostas (se no caso concreto, forem eficientes para a prevenção) porque realizam a ultima ratio da pena no direito penal. ${ }^{6263}$

Outra concepção de culpabilidade que é criticada por Claus Roxin foi difundida por Hans Welzel que parece ser a adotada pelo Tribunal Federal de Justiça da Alemanha. É chamada de teoria da culpabilidade material. O fundamento material da culpabilidade é a incorporação

\footnotetext{
${ }^{58}$ MELLO, 2010, p. 283.

59 Tradução livre de: “[...] no se trata de posibilitar al juez uma exención de pena conforme a sus propias representaciones políticocriminales, sino que se deben averiguar las hipótesis preventivas que sirven de base a a la ley". (ROXIN, 2006, p. 793).

${ }^{60}$ ROXIN, 2006, p. 793.

${ }^{61}$ SOUZA JUNIOR, 2011.

${ }^{62}$ EIBE, 2006, p. 442-443.

${ }^{63}$ É um conceito que nitidamente influenciou a lei brasileira $n^{\circ} 12.403 / 2011$ a qual elenca dez medidas cautelares diversas da prisão (com ressalva na compreensão ao inciso VII que trata da internação provisória).
} 
do conceito de "poder agir de outro modo". Esse conceito é compreendido hipoteticamente como se "alguém, naquela mesma situação, agiria de forma contrária" possibilitando a reprovação da conduta do infrator e the atribuindo pena. O Tribunal Federal de Justiça da Alemanha expressou seu entendimento culpabilidade associando-a com reprovabilidade e apontou que pelo "juízo de desvalor da culpabilidade se reprova o sujeito que não se tenha comportado conforme o Direito, que tenha decidido praticar o injusto podendo comportar-se conforme o Direito, podendo decidir-se pelo Direito". ${ }^{64}$

A dogmática-penal moderada, contudo, rejeita a teoria material pela impossibilidade de o direito penal os pressupostos exigíveis para a reprovação da conduta. Alega que desde a ideia de livre-arbítrio depara com a impossibilidade de comprovação, entretanto, ainda admitindo a concepção do livre-arbítrio não há como provar empiricamente que o indivíduo na situação em que se encontrava era dotado da liberdade de decidir agir conforme o direito, por conseguinte, parte de uma proposição não comprovável que conduzirá à absolvição pelo princípio do in dubio pro reo. ${ }^{65} \mathrm{O}$ autor cita Bockelmann para resistir à concepção da culpabilidade material que considerou ser "puro sem sentido" avaliar que "a pessoa mentalmente sã pode atuar livremente e que a essência da enfermidade mental consiste precisamente na supressão da liberdade de decidir". ${ }^{66}$

Os adeptos da teoria da culpabilidade material entendem que o exame do "poder agir de outro modo" é confrontado com o que a experiência demonstra como outra pessoa naquele lugar agiria - se conforme ao direito ou não. Retorna ao conceito normativista de Eberhard Schmidt de "homem médio" ${ }^{67}$ cuja concordância reverte em renúncia da valoração da conduta individual suprida por características que estariam presentes em outra pessoa. ${ }^{68}$ Nesse mesmo sentido Sebástian Borges de Albuquerque Mello assenta sua crítica à concepção da

${ }^{64}$ Tradução livre de: "Con el juicio de desvalor de la culpabilidad se le reprocha al sujeto que no se haya comportado conforme a Derecho, que se haya decidido por el injusto aunque habría podido comportarse conforme a Derecho, decidirse por el Derecho." (ROXIN, 2006, p. 799).

${ }^{65}$ ROXIN, 2006, p. 799-800.

${ }^{66}$ Tradução livre de: "[...] la persona mentalmente sana puede actuar libremente y que la esencia de la enfermedad mental consiste precisamente en la supresión de la libertad de elegir". (ROXIN, 2006, p. 799).

${ }^{67} \mathrm{O}$ conceito de "homem médio" funda-se nos estudos do estatístico belga Adolphe Quetelet (1796-1874) o qual, por cálculos matemáticos 'criou' o homem médio (média de altura, peso, inteligência); o conceito de "homem médio" advém de um valor matemático. O inglês Francis Galton (1822-1911) utilizou o resultado dos cálculos do estatístico belga para proceder a um indicador de mediocridade. Foi o início da eugenia, da ambição de aperfeiçoar a raça humana física e mentalmente iniciando com o processo de esterilização de 'idiotas e retardados'. (PETRY, 2011, p. 160-165).

${ }^{68}$ ROXIN, 2006, p. 800. 
“liberdade de agir de outro modo" porque "o juízo de censura é baseado em capacidades que poderiam estar presentes em outras pessoas, mas que justamente estão ausentes no autor”. ${ }^{69}$

O critério proposto por Claus Roxin na categoria da reprovabilidade é a análise dos elementos da culpabilidade conciliados com a necessidade de aplicação da pena, ambos valorados em cada caso concreto. Substitui o conceito de "poder atuar de outro modo" pela concepção de "dirigibilidade normativa” por entender que não há como saber efetivamente se o indivíduo podia atuar de outro modo, entretanto, julga ser possível precisar a disponibilidade do sujeito "para atender ao chamado normativo em face de seu estado mental e anímico". 70 Escreve que se no momento da conduta havia "uma capacidade de controle intacta" que viabilize a dirigibilidade (acessibilidade) normativa, então o sujeito será tratado como livre. ${ }^{71}$

Admoesta que o Direito deve supor a liberdade, mas não afirmar a sua existência porque não é passível de demonstração empírica, portanto, a liberdade é uma "afirmação normativa". ${ }^{72}$ Nesse sentido, a culpabilidade é uma categoria "mista empírico-normativo"; o que se comprova empiricamente é a capacidade geral de autocontrole e a disposição de se dirigir normativamente em virtude da própria capacidade intacta. ${ }^{73}$

No âmbito da inimputabilidade sobressai sua concepção pela configuração de sua dogmática penal harmonizada à compreensão de que o Direito Penal deve intervir apenas quando absolutamente indispensável à sociedade, portanto, argumenta que a absolvição de pessoas "mental ou psiquicamente enfermas e gravemente perturbadas em sua capacidade de motivação, assim como [das] imaturas ou [d]aquelas que não podiam alcançar o conhecimento das normas" não afeta a expectativa geral de que os seres humanos devem fidelidade ao direito porque dessas pessoas não se espera que observem as normas. ${ }^{74}$

Explica aos autores o contrassenso de compreenderem a culpabilidade como poder individual de agir, uma “ficção necessária para o Estado", sublinhando que a perspectiva é inversa, pois o princípio da culpabilidade é garantia do cidadão em face do Estado. Conclui que “a culpabilidade é, pelo contrário, uma 'garantia que pressupõe a liberdade' dirigida contra os excessos punitivos do Estado." 75

\footnotetext{
${ }^{69}$ MELLO, 2010, p. 281.

70 Ibid., p. 284.

${ }^{71}$ ROXIN, 2006, p. 808.

72 Ibid., loc.cit.

${ }^{73}$ lbid., p. 810.

${ }^{74}$ Ibid., p. 810, 811.

${ }^{75}$ Ibid., loc. cit.
} 
Pelo estudo dos conceitos da dogmática penal de Claus Roxin afirma-se uma teoria envolvida por ideais garantistas que se identifica mais proximamente com o Estado Democrático de Direito.

\section{CONCLUSÃO}

O paradigma da complexidade revela a necessidade de reestruturação das bases que fundamentam as ciências teóricas e práticas. Os fundamentos do Direito Penal são reelaborados pelas teorias funcionalistas a partir de sua função estabilizante e maior proximidade com o sistema social pela política criminal. A eficiência exige que os valores liberdade e segurança sejam reavaliados para determinar os limites do proibido e permitido, contudo, sem desprezar a evolução histórica das conquistas garantistas.

0 artigo confrontou as teorias funcionalistas sistêmico-radical e teleológicaaxiológica com o objetivo de determinar aquela que sopesa liberdade e segurança de modo mais consentâneo com o Estado Democrático de Direito. Iniciou pelos conceitos da dogmática penal funcionalista sistêmica de Günther Jakobs influenciada pela teoria dos sistemas do sociólogo Niklas Luhmann. O Direito Penal nessa configuração é orientado à confirmação da norma jurídica. A sanção penal é condição que revigora a expectativa social em relação às normas jurídicas; a violação à norma jurídica desafia a credibilidade do sistema jurídico cuja revalidação é promovida pela aplicação da sanção penal. A conexão que o sistema penal jakobsiano estabelece entre a culpabilidade e a finalidade da pena se circunscreve ao aspecto preventivo geral.

Destarte, afirma Günther Jakobs que pelo direito penal não se punem fatos, mas se pune a violação à norma. A crítica assinala um aspecto instrumental na teoria sistêmica em virtude da concentração na eficiência do sistema e menor espaço para a garantia individual. Apesar do giro conceitual no processo comunicacional entre sistema e sociedade - a partir de 1993 - Günther Jakobs mantém uma dogmática penal radical em que afirma ser a sociedade composto por seres humanos divididos em duas "categorias" e conclui por considerar "inimigos" da sociedade os indivíduos que eventualmente reincidem na violação ao ordenamento jurídico.

A teoria penal roxiniana, similarmente, conecta a culpabilidade aos fins da pena, entretanto não a reduz ao caráter preventivo geral. Elabora o conceito de "responsabilidade" 
cuja imputação é aferida, no caso concreto, segundo o ordenamento jurídico. Em contraposição Claus Roxin mantém em sua teoria penal a herança garantista da culpabilidade no direito penal. O funcionalismo de Claus Roxin pretende atender ao caráter axiológico da culpabilidade e recoloca o indivíduo no núcleo protetivo do ordenamento jurídico.

Pelo processo de confrontação entre as teorias funcionalistas apresentado no artigo demonstrou-se que a dogmática penal axiológica-teleológica de Claus Roxin guarda maior afinidade com perspectivas garantistas. Aqui os valores liberdade e segurança são mensurados de modo mais apropriado no contexto do Estado Democrático de Direito.

\section{REFERÊNCIAS}

BAUMAN, Zygmunt. Fronteiras do pensamento. Disponível em:

<HTTP://www.youtube.com/embed/POZcBNo-D4A. Acesso em: 11 jun. 2012.

BECCARIA, Cesare. Dos delitos e das penas. Tradução de Lucia Guidicini e Alessandro Berti Contessa. 3. ed. São Paulo: Martins Fontes, 2005.

BRASIL. Lei n. 12.403, de 04 de maio de 2011. Altera dispositivos do Decreto-Lei 3689, de 3 de outubro de 1941 - Código de Processo Penal, relativos à prisão processual, fiança, liberdade provisória, demais medidas cautelares, e dá outras providências. Diário Oficial (da) República Federativa do Brasil. Brasília, DF, 5 maio 2011. Disponível em:

<http://www.planalto.gov.br/ccivil_03/_Ato2011-2014/2011/Lei/L12403.htm>. Acesso em: 20 jun. 2012.

BRASIL. Supremo Tribunal Federal. Habeas Corpus 101.874/SC. DJe 159. Publicado em 27-082010. Disponível em:

<HTTP://www.stf.jus.br/portal/processo/verProcessoAndamento.asp?incidente=3807351. Acesso em: 11 jun. 2012.

BRASIL. Supremo Tribunal Federal. Recurso Extraordinário 580.252. Limites orçamentários do Estado. Indenização por dano moral. Excessiva população carcerária. Disponível em:

<HTTP://www.stf.jus.br/portal/processo/verProcessoAndamento.asp?incidente $=2600961$.

Acesso em: 11 jun. 2012.

CARVALHO, Aurora Tomazini. Teoria geral do direito: o constructivismo lógico-semântico. São Paulo, 2009. Dissertação (Doutorado em Filosofia do Direito) - Pós-Graduação em Direito da Pontifícia Universidade Católica de São Paulo, São Paulo. 
CORSI, Giancarlo; ESPOSITO, Elena; BARALDI, Claudio. Glosario sobre la teoria Social de Niklas Luhmann: prefacio de Niklas Luhmann. México: Universidad Iberoamericana, 1996.

DÍAZ, Myrna Villegas. El Mapuche como enemigo em el Derecho (Penal): consideraciones desde la biopolítica y el derecho penal del enemigo. Espanha: Instituto de Derecho Penal Europeo e Internacional, 2010. Disponível em: <http://cienciaspenales.net>. Acesso em 11 jun. 2012.

DINIZ NETO, Eduardo. Sociedade de risco, direito penal e política criminal. Revista de Direito Público, Londrina, v. 5, n. 2, p. 202-220, ago. 2010.

EIBE, Manuel José Arias. Funcionalismo penal moderado o teleológico-valorativo Versus Funcionalismo Normativo o Radical. Doxa: Cuadernos de Filosofia del Derecho, Alicante, n. 29, p. 439-453, 2006.

FILHA de Giuliani é presa em loja de cosméticos em Manhattan. 0 Globo Online, Disponível em: <http://oglobo.globo.com/mundo/filha-de-giuliani-presa-em-loja-de-cosmeticos-em-manhattan2969885>. Acesso em: 21 maio 2012.

FONSECA, Mariana Martins de Castilho. Uma análise da contribuição do funcionalismo de Claus Roxin à teoria da ação. Revista da Faculdade de Direito UFMG. Belo Horizonte: Universidade Federal de Minas Gerais, n. 54, p. 157-178, jan./jun. 2009.

GOMES, Sergio Alves. Hermenêutica Constitucional: um contributo à construção do Estado Democrático de Direito. 2. ed. Curitiba: Juruá, 2010.

GUIRÃO, Rafael Alcácer. Prevención y garantias: conflicto y síntesis. Doxa: Cuadernos de Filosofía del Derecho, Alicante, n. 25, p. 5-11, 2002.

HERNANDES, Javier C. A familiar face in peru, and a more local recruiting effort. The New York Times, New York, 18 maio 2011. Disponível em <http://cityroom.blogs.nytimes.com /2011/05/18/a-familiar-face-in-peru-and-a-more-local-recruiting-effort/>. Acesso em: 18 maio 2011.

HESSE, Konrad. A força normativa da Constituição. Tradução de Gilmar Ferreira Mendes. Porto Alegre: Sergio Antonio Fabris, 1991.

JAKOBS, Günther. A imputação objetiva no direito penal. Tradução de André Luís Callegari. São Paulo: Revista dos Tribunais, 2000.

. Fundamentos do direito penal. Tradução de André Luís Callegari. São Paulo: Revista dos Tribunais, 2003.

KAFKA, Franz. América. Tradução de Torrieri Guimarães. Belo Horizonte: Itatiaia, 2000.

LIPTAK, Adam. Justices Order California to Shed 30,000 Prisoners. The New York Times, Nova lorque, 23 maio de 2001. Disponível em:

<HTTP://www.nytimes.com/2011/05/24/us/24scotus.html/?pagewanted=1\& $\mathrm{r}=1 \mathrm{\& smid=tw}$ nytimes\#. Acessado em 23-05-2011. 
MATZENBACHER, Alexandre; TONET, Fernando. Kafka e a tolerância zero: uma abordagem da política criminal a partir da literatura. In: SCHWARTZ, André Trindade e Germano (Coord.). Direito e Literatura: o encontro entre Themis e Apolo. Curitiba: Juruá, 2008.

MELLO, Sebástian Borges de Albuquerque. A evolução do conceito de culpabilidade e a moderna doutrina alemã. Revista de Ciências Penais, São Paulo, v. 12, p. 125, 2010.

MITCHELL, Peter R; SCHOEFFEL, John (Org.). Para entender o poder: o melhor de Noam Chomsky. Tradução de Eduardo Francisco Alves. Rio de Janeiro: Bertrand Brasil, 2005.

NAVARRO, Evaristo Prieto. Teoría de sistemas, funciones del derecho y control social: perspectivas e imposibilidades para la dogmática penal. Doxa: Cuadernos de Filosofía del Derecho, Alicante, n.23, p. 265-278, 2000.

NEVES, Clarissa Eckert Baeta; NEVES, Fabrício Monteiro. O que há de complexo no mundo complexo? Niklas Luhmann e a Teoria dos Sistemas Sociais. Sociologias, Porto Alegre, v. 8, n. 15, 182-207, jan./jun. 2006.

PETRY, André. O Que é ser Normal: novos estudos revolucionam o conceito de saúde mental. Veja, São Paulo, v. 44, n. 47, p. 160-165, nov. 2011.

RIPOLLÉS, José Luis Díez. Da sociedade do risco à segurança cidadã: um debate desfocado. Revista Portuguesa de Ciência Criminal, Coimbra, ano 17, n. 4, p. 202-220, out./dez. 2007.

ROXIN, Claus. Derecho penal: parte general. Tradução de Diego-Manuel Luzón Peña, Miguel Díaz y García Conlledo e Javier de Vicente Remesal. Madri: Thomson Civitas, 2006. T. 1:

Fundamentos. La Estructura de la Teoría del Delito, tomo 1.

SOUZA JUNIOR, Carlos Miguel de. Funcionalismo Penal: aportes sobre uma teoria axiológica do direito penal. Sistema Penal \& Violência. Porto Alegre: Revista Eletrônica da Faculdade de Direito, v. 3, n. 1, p. 62-73, jan./jun. 2011.

Recebido em: 29.09.2013

Correções em: 26.11.2013

Aprovado em: 29.12.2013 